\title{
Multiple Myeloma in Unusually Young Patient: A Case Report
}

\author{
Fatima Ez-Zahra El Mangad, Imane El Bouchti \\ Rheumatology Department, Mohammed VI University Hospital, Marrakesh, Morocco \\ Email: fz.elmangad@gmail.com
}

Received 12 June 2014; revised 11 July 2014; accepted 10 August 2014

Copyright (C) 2014 by authors and Scientific Research Publishing Inc.

This work is licensed under the Creative Commons Attribution International License (CC BY). http://creativecommons.org/licenses/by/4.0/

(c) (i) Open Access

\begin{abstract}
Multiple myeloma, a disease of elderly, is extremely rare in those about 30 years of age. A patient with MM diagnosed at age 27 is described. He was a male with a four-month history of back pain and later, hemurus and tibia pain persisting despite NSAIDS. X-rays had shown lytic lesions on lateral radiograph of the skull and the humerus. His ESR was $120 \mathrm{~mm}$. Serum calcium was 125 $\mathrm{mg} / \mathrm{l}$ and glomerular filtration rate at $25 \mathrm{ml} / \mathrm{min}$. There was a beta2 peak in the serum protein electrophoresis. The Immunohistochemical examination demonstrated a strong reaction for the Lambda light chain in all tumor cells. Bence Jones protein was present in urine. Bone marrow biopsy confirmed the diagnosis of multiple myeloma. Our patient was treated with dexamethasone, zoledronic acid, cyclophosphamide and thalidomide with good evolution. Actually, he was proposed for stem cell transplantation. This report illustrated that multiple myeloma should be even evoked in young patients.
\end{abstract}

\section{Keywords}

\section{Multiple Myeloma, Young Person}

\section{Introduction}

Multiple myeloma (MM) is a neoplastic plasma-cell disorder that is characterized by clonal proliferation of malignant plasma cells in the bone marrow microenvironment, monoclonal protein in the blood or urine, and associated organ dysfunction. The median age at diagnosis is approximately 70 years [1]. Less than $2 \%$ of patients are younger than 40 years of age at diagnosis and it is extremely rare in those younger than 30 years [2]. We report a case of multiple myeloma in a young patient aged 27 years.

\section{Case Report}

A 27-year-old man presented 4 months history of an inflammatory pain of cervical spine with radicular pain and 
later, weakness of both humerus and tibia. The man presented also, vomiting and significant asthenia. Clinical examination showed a young man in fair general health. He had tenderness over lumbar spine without features of cord compression. The other systems were normal.

Laboratory examination revealed an anemia (Hemoglobin level at 7.3/dl), an increased erythrocyte sedimentation rate $(\mathrm{ESR}=120 \mathrm{~mm})$. The hypercalcemia was important (Corrected calcium level at $125 \mathrm{mg} / \mathrm{l})$. Renal function has been altered (GFR $=25 \mathrm{ml} / \mathrm{min}$ ).

X-rays showed several lytic lesions on lateral radiograph of the skull (Figure 1), and thehumerus. On MRI studies, there were a diffuse vertebral impairment with destruction of vertebral body of cervical, dorsal, lumbosacral spine and iliac wings. It revealed an anterior and posterior epidural infiltration (Figure 2).

There was a beta2 peak in the serum protein electrophoresis (Figure 3). The Immunohistochemical examination demonstrated a strong reaction for the Lambda light chain in all tumor cells. Bence Jones protein (BJP) was present in urine. A subsequent bone marrow examination showed 10\% plasma cells.

Our patient was treated with dexamethasone, zoledronic acid, cyclophosphamide and thalidomide with good evolution. Currently, he is proposed for stem cell transplantation.

\section{Discussion}

MM is a malignant disorder which is characterized by the proliferation of monoclonal plasma cells [2]. The peak incidence of MM is in the seventh decade, whereas, it is a rare entity in young patients, with less than $2 \%$ cases

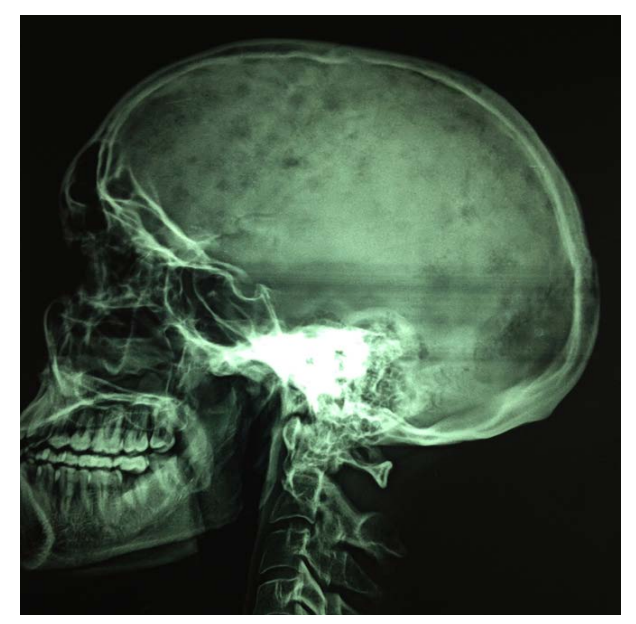

Figure 1. Lateral radiograph of skull showing several lytics lesions.

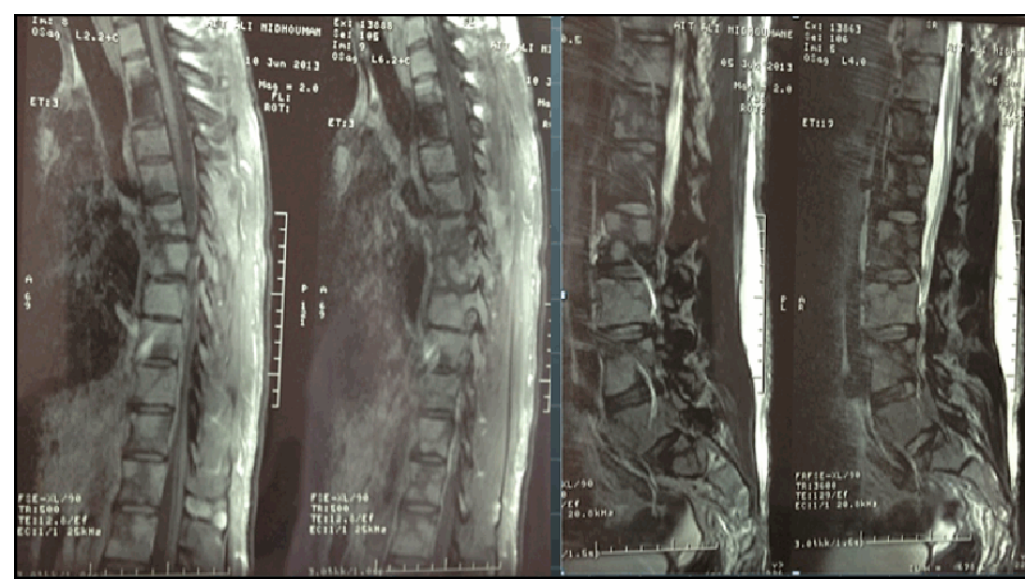

Figure 2. MRI shows destruction of vertebral body of cervical, dorsal, lumbosacral spine and iliac wings with an anterior and posterior epidural infiltration. 


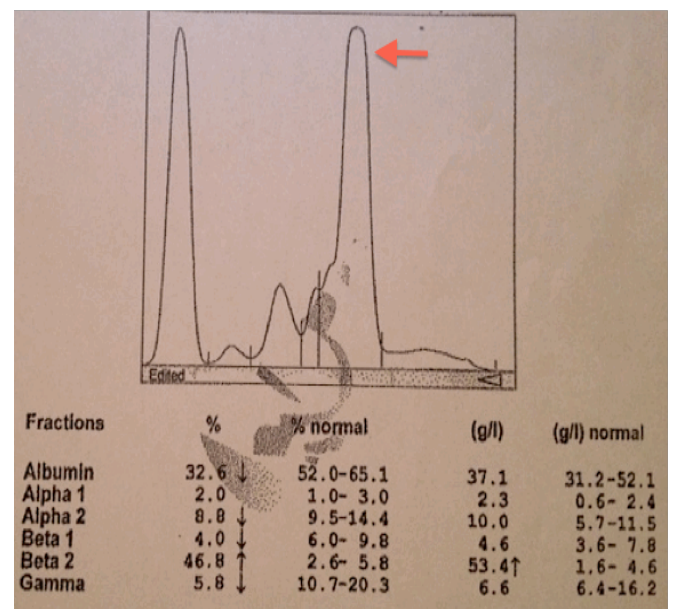

Figure 3. Beta2 peak in the serum protein electrophoresis.

occurring in patients under the age of 40 years and it is still rarer in patients who are younger than 30 years [3].

In the study by National Cancer Institute, the frequency of such occurrence was 7/3815 (0.18\%) [4]. Hewell et al. have reported frequency of $1 \%$ [5]. These patients were the first well-documented group of young persons with MM. The records of all patients younger than 30 years with MM evaluated at the Mayo Clinic were reviewed and the incidence was found as $0.3 \%$ [2].

MM in the young has an atypical clinical presentation with multiple or solitary extra medullary plasmocytoma and osteolytic lesions, but low serum or urinary monoclonal M proteins, and few or no plasma cells in the bone marrow [2] [5]. The clinical behavior of multiple myeloma in adolescents and young adults has been suggested to be more indolent [6] [7]. However, our young patient has a typical clinical presentation.

Renal function impairment is a well-known complication of MM. A Mayo clinic analysis revealed renal function impairment and hypercalcaemia in $30 \%$ and $20 \%$ of the patients, respectively [2]. In our patient, there was an evidence hypercalcaemia, and renal impairment requiring renal dialysis.

Lazarus et al. reported two cases of plasma cell myeloma in young patients [7]. One was a case of MM involving the skull and ribs in a 23-year-old woman; the other was a solitary myeloma of the tibia in a 21-yearold man. Both the cases were diagnosed non-secretory multiple myeloma. However, monoclonal immunoglobulin was demonstrated by immuno-histochemical studies. In our observation, there was a beta2 peak in the serum protein electrophoresis. The Immunohistochemical examination demonstrated a strong reaction for the Lambda light chain in all tumor cells with a positive Bence Jones protein (BJP) in urine. However, only the report by Blade et al. found BJP in 5 out of 10 patients [2].

Litterature review suggests that there may be an associated extramedullary component in most of these patients. Geetha et al. from India described two young patients (20 years, 18 years) who presented with extradural cord compression, lytic bone lesions and bone marrow plasmacytosis [8].

The median duration of survival of patients with MM ranges between 2 - 3 years. In the study from Mayo clinic, the median duration of survival of the patients was 87 months. The survival of the younger patients was considerably longer than that of patients of all ages with MM [5]. These results support the beneficial effect of a very young age on survival in patient with myeloma.

\section{Conclusion}

In conclusion, this report illustrates that multiple myeloma should be even evoked in young patients, especially if there are evocative biological or radiological signs.

\section{Conflicts of Interest Statement}

The authors have declared no potential conflict of interests. 


\section{References}

[1] Antonio, P. and Kenneth, A. (2011) Multiple Myeloma. The New England Journal of Medicine, 364, 1046-1060. http://dx.doi.org/10.1056/NEJMra1011442

[2] Blade, J., Kyle, R.A. and Greipp, P.R. (1996) Multiple Myeloma in Patients Younger Than 30 Years. Report of 10 Cases and Review of the Literature. Archives of Internal Medicine, 156, 1463-1468. http://dx.doi.org/10.1001/archinte.1996.00440120125014

[3] Ishida, T. and Dorfman, H.D. (1995) Plasma Cell Myeloma in Unusually Young Patients: A Report of Two Cases and Review of Literature. Skeletal Radiology, 24, 47-51. http://dx.doi.org/10.1007/BF02425947

[4] Blade, J., Kyle, R.A. and Greipp, P.R. (1996) Presenting Features and Prognosis in 72 Patients with Multiple Myeloma Who Were Younger Than 40 Years. British Journal of Haematology, 93, 345-351. http://dx.doi.org/10.1046/j.1365-2141.1996.5191061.x

[5] Hewell, G.M. and Alexanian, R. (1976) Multiple Myeloma in Young Persons. Annals of Internal Medicine, 84, 441-443. http://dx.doi.org/10.7326/0003-4819-84-4-441

[6] Rappaport, A.P. and Rowe, J.M. (1990) Plasma Cell Dyscrasia in a 15 Year Old Boy. Case Report and Review of Literature. The American Journal of Medicine, 89, 816-818. http://dx.doi.org/10.1016/0002-9343(90)90229-7

[7] Lazarus, H.M., Kellermeyer, R.W., Aikawa, M. and Herzig, R.H. (1980) Multiple Myeloma in young Men. Clinical Course and Electron Microscopic Studies of Bone Marrow Plasma Cells. Cancer, 46, 1397-1400. http://dx.doi.org/10.1002/1097-0142(19800915)46:6<1397::AID-CNCR2820460618>3.0.CO;2-F

[8] Geetha, N., Jayaprakash, M., Rekhanair, A., Ramachandran, K. and Rajan, B. (1999) Plasma Cell Neoplasma in the Young. The British Journal of Radiology, 72, 1012-1015. http://dx.doi.org/10.1259/bjr.72.862.10673955 
Scientific Research Publishing (SCIRP) is one of the largest Open Access journal publishers. It is currently publishing more than 200 open access, online, peer-reviewed journals covering a wide range of academic disciplines. SCIRP serves the worldwide academic communities and contributes to the progress and application of science with its publication.

Other selected journals from SCIRP are listed as below. Submit your manuscript to us via either submit@scirp.org or Online Submission Portal.
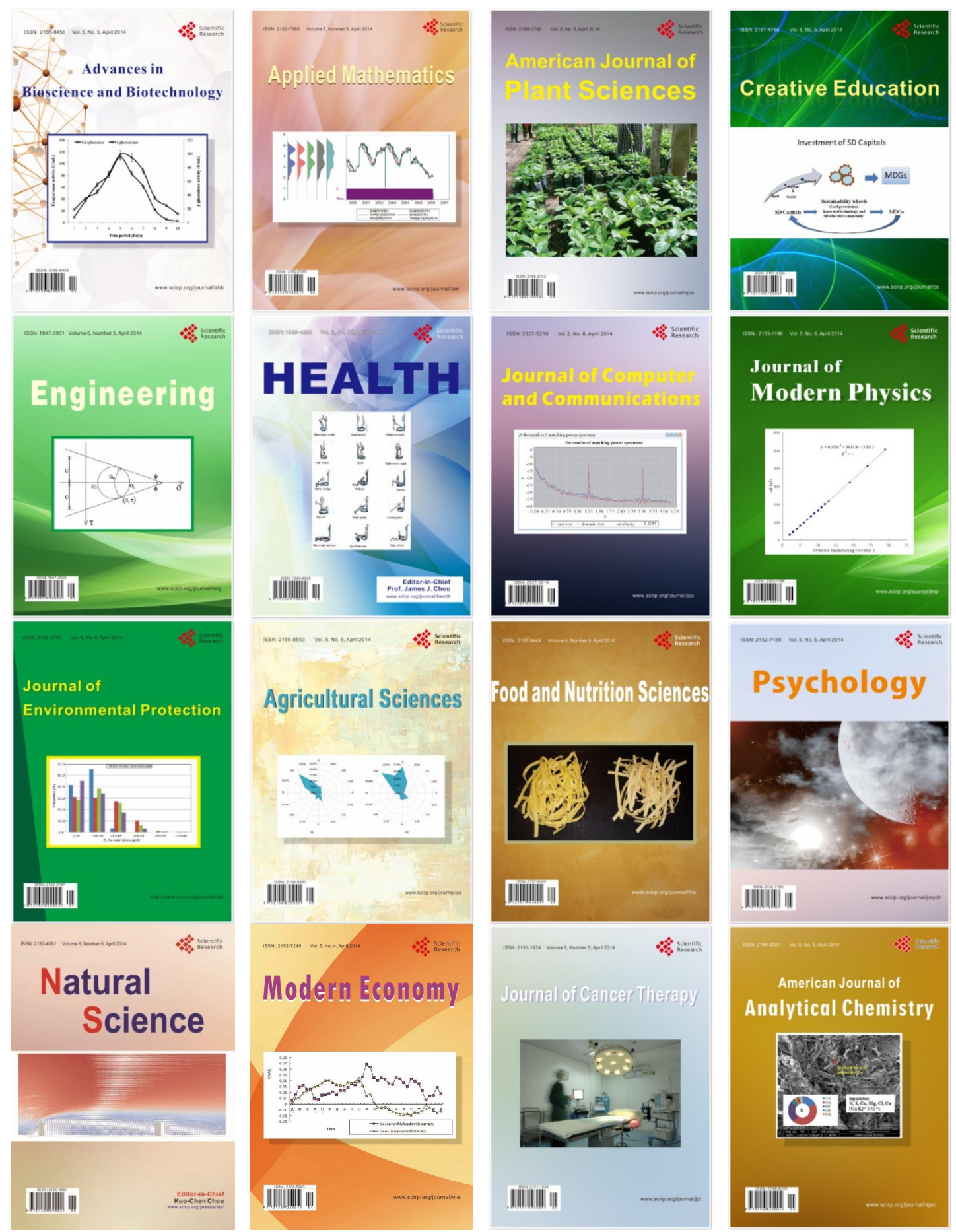